\title{
Hubungan antara Penyesuaian diri dan Kontrol diri dengan Perilaku Delikuen pada siswa SMA Muhammadiyah 1, Jombang
}

\author{
Haryanti Tri Darmi Titisari \\ Universitas Muhammadiyah, Malang. \\ Email : ning.iip81@gmail.com
}

\begin{abstract}
Adolescence is a transitional period in physical and psychological development that is influenced by several factors including the environment. Self-control and self-adjustment have an important role in the development so that adolescents do not have a tendency to behave delinquently when they are in the new community and environment. On this basis, this study aims to determine the relationship between self-control and self-adjustment with delinquency behavior in adolescents. The population in this study was students of grade $10^{\text {th }}$, and sampling was taken by using saturation sampling technique for 98 students and using self-control questionnaire, adjustment, and delinquency behavior. Statistics applied Spearman correlation technique and data were processed by using computer program SPSS series 22 for IBM for Windows. The result of the analysis shows the significance value was 0.721, and the correlation coefficient was -0.037 between Self-control with Delinquency, as well as the significance value of 0.345 and the correlation coefficient of -0.096 in Self-Adjustment with Delinquency ( $p>0.05)$. This indicates that there was no significant relationship between Self-Control and Adjustment to Delinquency behavior.
\end{abstract}

\section{Keywords: Self Control, Self Adjusment, Juvenile Delinquency}

\section{PENDAHULUAN}

Manusia diciptakan Allah, sesungguhnya dibekali dengan berbagai potensi, namun terkadang kemampuan tersebut pada umumnya tidak disadari, sehingga sedikit sekali yang mampu memahami dan memanfaatkan potensi yang dimiliki. Hal ini bisa dialami oleh setiap individu pada setiap masa perkembangannya, terutama pada individu yang sedang berada dalam masa transisi untuk tahapan masa perkembangannya, seperti pada masa remaja awal yang merupakan masa peralihan dari satu tahap perkembangan ke tahap berikutnya. Hal ini berarti bahwa sesuatu yang terjadi sebelumnya akan meninggalkan bekasnya pada sesuatu yang terjadi sekarang serta akan mempengaruhi pola perilaku dan sikap yang baru yaitu lingkungan yang ada di sekitarnya yang juga turut andil dalam mempengaruhi segala tingkah lakunya seperti orang-orang yang paling dekat yang merupakan bagian dari cerita hidupnya, seperti orang tua, saudara kandung, sanak saudara, para kerabat, guru atau bahkan teman sebaya dan para sahabatnya.

Persahabatan merupakan konteks yang sangat penting terutama selama masa remaja, untuk pengembangan kedua individu dalam sikap dan manifestasi perilaku yang sifatnya membangun (Hartup 1996; Piehler and Dishion 2007). Bahkan beberapa berpendapat bahwa kelompok sebaya menjadi konteks yang lebih penting bagi kaum muda daripada bagi para orang tua, terutama dalam hal 
pengaruh mereka pada pengambilan keputusan dalam jangka pendek (Harris 1995; Thornberry 1987). Kualitas hubungan dalam persahabatan sangat bervariasi, dan hubungan yang bisa memacu konflik dengan teman, mungkin sangat bermasalah bagi remaja yang terlibat dalam perilaku antisosial dan menyimpang, termasuk kecenderungan dalam berperilaku delinkuen.

Kasi Pencegahan BNNP (Badan Narkotika Nasional Propinsi) Jatim, Danang Sumiharta mengatakan bahwa Di Provinsi Jawa Timur sendiri, jumlah penyalahguna narkoba tercatat 568.309 orang, atau $2,1 \%$ dari jumlah penduduk di daerah ini. Di tingkat nasional, Jatim berada di peringkat 3. Sedangkan secara nasional, jumlah penyalah guna narkoba lebih dari 4 juta, atau 2,2\% dari jumlah penduduk Indonesia. Dari jumlah penyalahguna narkoba itu, yang terbesar adalah kalangan remaja, pelajar dan mahasiswa. "Pengguna narkoba dari kalangan pelajar dan mahasiswa di Jatim terbesar di Indonesia". Perilaku yang lain juga sering terjadi dalam masyarakat, seperti dengan berita di bulan April 2016 tentang kasus bullying di kalangan pelajar yang terjadi di gresik dimana geng cewek abg yang menyiksa siswa sekolah lain hanya gara-gara identitas pada akun BlackBerry Massenger (BBM). Kasus-kasus yang sama juga sering terjadi sebelumnya, misalnya saja sekelompok remaja putri yang tergabung dalam geng Nero di Pati jawa tengah, yang menampar korbannya berulangulang dan sering menganiaya, serta merekamnya lewat video telepon seluler (ponsel) dan kemudian mengedarkannya (jawa pos, 2008).

Hartup dan Stevens (1997) mengartikulasikan pemahaman pada penelitiannya, bahwa memiliki teman bisa membangun atau memberikan dukungan yang baik, selain itu teman juga memiliki faktor resiko, karena dapat meningkatkan probabilitas perilaku yang bermasalah. Definisi dari kualitas dalam persahabatan adalah sebagai multidimensi yang dibangun oleh kedua individu dengan melihat dalam afektif kedekatan, keamanan, bantuan, arti persahabatan itu sendiri, dan kurangnya konflik satu dengan yang lain. Young (2011) menemukan bahwa tingkat pengendalian diri dari individu baik mempengaruhi kualitas persahabatan yang dibentuk atau membuat stres yang akhirnya mengarah pada kesulitan dalam persahabatan dan perilaku delinkuen.

Siegel \& Wesh (dalam N., Nindya P. \& R., Margaretha, 2012) menganggap bahwa keluarga, sekolah, dan teman sepermainan merupakan faktor penyebab dari perilaku kenakalan pada remaja. Banyak ahli yang percaya bahwa keluarga yang bermasalah merupakan penyebab utama dalam pembentukan masalah emosional pada anak yang dapat mengarah pada masalah sosial dalam jangka panjang. Orang tua yang mengacuhkan atau tidak memenuhi kebutuhan anak dengan baik akan meningkatkan resiko keterlibatan anak dalam perilaku sosial yang tidak dapat diterima, seperti agresi dan masalah perilaku ekternal lainnya (Veerlan \& Schwartzman, 2002).

Penelitian yang dilakukan oleh Iga Serpianing Aroma \& Dewi Retno Suminar (2012) tentang Hubungan antara Tingkat Kontrol Diri dengan Kecenderungan Perilaku Kenakalan Remaja dengan memakai alat pengumpulan data berupa skala psikologi, dengan hasil penelitian bahwa semakin tinggi skor pada kontrol diri, maka semakin rendah kecenderungan perilaku kenakalan pada remaja. Penelitian lainnya tentang penyesuaian diri yang berkaitan dengan perilaku delinkuen,telah dilakukan oleh Yuyuk Neni Yuniarti (2009) yang menunjukkan hasil peneitiannya bahwa persepsi efektivitas komunikasi interpersonal orang tua dan kematangan emosi memberikan sumbangan efektif sebesar $51,1 \%$ terhadap penyesuaian diri pada 
remaja, dengan sumbangan efektif masing-masing variabel adalah 35,2\% untuk persepsi efektivitas komunikasi interpersonal orang tua dan $15,9 \%$ untuk kematangan emosi. Hal ini berarti masih ada $48,9 \%$ faktor lain yang mempengaruhi penyesuaian diri pada remaja.

$$
\text { Gottfredson dan Hirschi }
$$

(1990)dalam teori umum tentang kontrol diri atau pengendalian diri, berpendapat bahwa individu dengan kontrol diri atau pengendalian diri yang rendah, memliki karakteristik yang stabil yang meningkatkan seseorang untuk melakukan tindakan-tindakan pidana atau tindakan yang menyimpang lainnya dalam kehidupan bersosial, dengan demikian dibutuhkan penyesuaian diri individu dengan karakteristik teman yang berbeda. Respon penyesuaian diri, baik atau buruk, secara sederhana dapat dipandang sebagai suatu upaya organisme untuk mereduksi atau menjauhi ketegangan dan untuk memelihara keseimbangan yang lebih dan didukung oleh pengendalian diri yang kuat, dengan demikian penyesuaian dan kontrol diri memiliki hubungan pada perilaku individu dalam memperkuat dan pengendalian diri dari pengaruh perilaku yang tidak sesuai dengan harapan lingkungan sosial yan ada di sekitarnya. Namun, dengan kesabaran individu bisa menghadapi masalah dalm kehidupannya. Allah SWT berfirman dalam Q.S. Al-Insyirah (5-6):

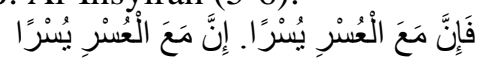

Yang artinya: "Karena Sesungguhnya sesudah kesulitan itu ada kemudahan"

Berdasarkan uraian diatas, peneliti mengurai rumusan masalah tentang apakah ada hubungan antara kontrol diri dengan perilaku delinkuen, antara penyesuaian diri dengan perilaku delinkuen, serta adakah hubungan antara kontrol diri dan penyesuaian diri dengan perilaku delinkuen pada remaja.

Tujuan dari penelitian ini adalah untuk membuktikan hubungan antara kontrol diri dengan perilaku delinkuen, antara penyesuaian diri dengan perilaku delinkuen, serta hubungan antara kontrol diri dan penyesuaian diri dengan perilaku delinkuen pada remaja.

Penelitian ini diharapkan mampu memberikan manfaat dan menambah bukti empiris tentang Kontrol Diri dan Penyesuaian Diri yang berhubungan dengan Perilaku Delikuen pada Remaja untuk perkembangan ilmu Psikologi, khususnya Psikologi Pendidikan dan Perkembangan.

Penelitian ini diharapkan bisa bermanfaat sebagai bahan informasi untuk belajar menyesuaikan diri pada situasi, kondisi, dan dengan lingkungan yang baru termasuk komunitas baru, sehingga remaja mampu mengendalikan diri dan terhindar dari kecenderungan perilaku yang tidak sesuai dengan aturan dan norma-norma yang sehingga remaja mampu melaksanakan tugas-tugas perkembangannya.

Penelitian ini diharapkan bisa bermanfaat dan mampu memberikan tambahan informasi tentang pentingnya pengendalian dan penyesuaian diri pada peserta didik, selain itu diharapkan bisa membantu lembaga pendidikan, dalam hal ini BK (Bimbingan Konseling) Sekolah dalam pengembangan program intervensi dengan bimbingan dan pendampingan agar siswa terhindar dari kecenderungan perilaku delikuen yang bisa saja ditularkan oleh komunitas dan lingkungan yang baru.

Kartono (1992), berpendapat bahwa Perilaku Delikuen (Kenakalan) pada remaja merupakan gejala sakit (patologis) secara sosial, yang terjadi pada anak dan remaja dan disebabkan oleh satu bentuk pengabdian sosial dan merangsang mereka untuk membongkar tingkah laku yang menyimpang. Kecenderungan perilaku delikuen (kenakalan) pada remaja, memiliki dua aspek yaitu: secara lahiriah (Verbal dan non Verbal); dan secara simbolik tersembunyi (sikap hidup, emosi-emosi dalam diri remaja, dan motivasi-motivasi 
yang bisa merangsang dan mengembangkan delikuen pada remaja). Maksud dari kecenderungan perilaku delikuen (kenakalan) remaja pada aspek lahiriah adalah aspek perilaku delikuen yang ditunjukkan secara verbal seperti memaki, mencela, atau menyerang orang lain secara verbal. Sedangkan aspek non verbal adalah aspek perilaku delikuen yang ditunjukkan secara fisik misalnya saja memukul, atau perilaku lain yang sifatnya menyerang secara fisik baik itu dilakukan secara personal atau dilakukan secara bersama-sama dengan kelompoknya seperti tawuran, dan sebagainya.Kecenderungan perilaku delikuen (kenakalan) pada remaja secara simbolik adalah perilaku-perilaku remaja yang berhubungan dengan bagaimana sikap hidup remaja dalam memaknai setiap perilaku hidup yang ada disekitarnya, dan mengendalikan setiap emosi dalam dirinya yang berpengaruh dan memiliki peran aktif dalam motivasimotivasi yang bisa merangsang dan mengembangkan perilaku delikuen dalam diri remaja.

Menurut Mulyono, beberapa bentuk karakteristik dari perilaku Delikuen terbagi dalam dua kelompok yaitu: Kenakalan yang bersifat amoral dan anti sosial yang tidak diatur oleh undang-undang sehingga kenakalan yang seperti ini tidak dapat dikatakan sebagi pelanggaran hukum; dan Kenakalan yang bersifat melanggar hukum dan penyelesaiannya yang sesuai dengan undang-undang dan hukum yang berlaku. Kenakalan ini seperti berjudi, mencuri, menjambret, merampok, menggelapkan barang, penipuan, dan pemalsuan, memiliki dan membawa senjata tajam yang dapat membahayakan orang lain, percobaan atau terlibat dalam pembunuhan, dan penganiayaan. Aroma, I. S., \& Suminar, D. R. (2012), menyatakan tentang karakteristik atau ciri remaja yang memiliki kecenderungan berperilaku delinkuen yang akan dijadikan sebagai indikator tingkah laku yaitu antara lain: (1) Kenakalan yang melawan status (mengingkari status anak sebagai pelajar dengan cara membolos, minggat dari rumah, membantah perintah); (2) Kenakalan yang menimbulkan korban fisik (tawuran antar sekolah, berkelahi dengan teman satu sekolah, pemerkosaan, pembunuhan dan lain sebagainya); (3) Kenakalan yang menimbulkan korban materi (memalak, merusak fasilitas sekolah maupun fasilitas umum lainnya dan lain-lain); (4) Kenakalan yang membahayakan orang lain dan diri sendiri (pelacuran, hubungan seks bebas, narkoba dan lain sebagainya. Walgito menyebutkan beberapa faktor yang mempengaruhi kenakalan (perilaku delikuen) pada remaja yaitu Faktor Keluarga, Faktor Keadaan Sekolah, Faktor Keadaan Masyarakat. Sukemi dan Warsito mengatakan bahwa penyebab timbunya kecenderungan perilaku delikuen adalah, Kurangnya pendidikan agam baik dalam keluarga maupun dalam masyarakat; Kurangnya perhatian orang tua terhadap anak; Kurangnya waktu luang yang berkualitas bagi anak dalam keluarga; Tidak adanya kestabilan keadaan sosial, politik dan ekonomi; Terjadinya kemerosotan moral dan mental orang dewasa; Banyak sekali tontonan-tontonan dan bacaan-bacaan negatif yang mudah diakses oleh masyarakat termasuk remaja; Perhatian masyaraat terhadap pendidikan anak, masih belum menyeluruh; Beberapa usaha dalam mengahadapi kenakalam pada remaja atau anak, yang tidak dapat diterima dan menimbulkan alternatif penyaluran yang negatif oleh anak. Secara umum penyebab kecenderungan perilaku delikuen pada remaja, berasal dari aspek intern dari dalam individu sendiri, dan aspek ekstern, dalam hal ini adalah lingkungan sekitar individu yang turut andil dalam membentuk perilaku seseorang. Menurut Corey, sikap itu dapat dibentuk sesuai dengan kemauan yang membentuknya, dan pembentukan 
sikap itu melalui proses pendidikan dan komunikasi yang berkualitas.

Chaplin (2006) berpendapat bahwa definisi dari Kontrol diri merupakan kemampuan untuk membimbing tingkah laku sendiri dalam menekan dan merintangi impils atau tingkah laku yang bersifat impulsif. Kontrol diri ini berfungsi sebagai kemampuan untuk menahan tingkah laku yang dapat merugikan orang lain, dimana mereka memiliki kontrol diri yang baik juga dan akan mengikuti peraturan yang ada. Berdasarkan konsep dari Goldfried dan Marbaum (Muhid, 2009), maka dapat disimpulkan bahwa kontrol diri merupakan mekanisme yang dapat membantu mengatur dan mengarahkan perilaku individu.

Mesina dan Mesina (dalam Gunarsa, 2004), menyebutkan bahwa pengendalian diri (kontrol diri) mempunyai fungsi-funsi seperti: Membatasi perhatian individu terhadap orang lain; Membatasi keinginan individu untuk mengendalikan orang lain dalam lingkungannya; Membatasi individu untuk bertingkah laku negatif; Membantu individu dalam memenuhi kebutuhannya secara seimbang. Bahkan Logue dan Forzano (1995), karakteristik atau ciri remaja yang mampu memiliki kontrol diri yang tinggi, yang akan dijadikan sebagai indikator penelitian adalah: (1) Tekun dan tetap bertahan dengan tugas yang harus dikerjakan, walaupun menghadapi banyak hambatan; (2) Dapat mengubah perilaku menyesuaikan dengan aturan dan norma yang berlaku dimana ia berada; (3) Tidak menunjukkan perilaku yang emosional atau meledak-ledak; (4) Bersifat toleran atau dapat menyesuaikan diri terhadap situasi yang tidak dikehendaki.

$\begin{array}{ccr}\text { Penyesuaian } & \text { diri } & \text { menurut } \\ \text { William (1991), } & \text { adalah } & \text { suatu }\end{array}$ kemampuan seseorang untuk hidup dan bergaul secara wajar terhadap lingkungan sehingga individu merasa puas terhadapa dirinya dan terhadap lingkungannya.
Gerungan (1991) juga berpendapat bahwa Penyesuaian diri merupakan suatu kemampuan manusia untuk mengubah diri sesuai dengan lingkungan dan mengubah lingkungan sesuai dengan keinginan diri, sejauh tidak menimbulkan konflik bagi dirinya dan tidak melanggar norma-norma yang berlaku dalam masyarakat. Penyesuaian diri adalah proses untuk mencoba mempertemukan tuntutan diri dan tuntutan lingkungan (Davidoff, 1991). Berdasarkan konsep dari Kartini Kartono (1995), maka dapat disimpulkan bahwa Penyesuaian diri adalah suatu usaha manusia untuk mencapai suatu keharmonisan pada diri sendiri dan pada lingkungannya.

Ali \& Asrori (2004), beberapa karakteristik penyesuaian diri khususnya bagi remaja adalah Penyesuaian diri tehadap peran dan identitas, Penyesuaian diri terhadap pendidikan, Penyesuaian diri terhadap kehidupan seks, Penyesuaian diri terhadap norma sosial, Penyesuaian diri terhadap penggunaan waktu luang, Penyesuaian diri terhadap penggunaan uang, Penyesuaian diri terhadap kecemasan, konflik, dan frustasi. Remaja seringkali dihadapkan pada kecemasan, konflik, dan frustasi karena perkembangannya yang dinamis. Strategi penyesuaian diri terhadap kecemasan, konflik, dan frustastasi tersebut biasanya melalui suatu mekanisme yang oleh freud (dalam Corey, 1989) disebut dengan mekanisme pertahanan diri. Cara-cara yang ditempuh ada yang cenderung negatif atau kurang sehat dan ada pula yang positif. Dalam batas-batas kewajaran dan situasi tertentu, untuk sementara memang masih memberikan manfaat dalam upaya penyesuaian diri remaja. Namun, jika cara-cara tersebut seringkali ditempuh dan menjadi kebiasaan, maka hal itu akan menjadi tidak sehat. Konsep dari Subsada (dalam Sarwono, 1995), karakteristik atau ciri dari penyesuaian diri yang akan dijadikan sebagai indikator penelitian adalah sebagai berikut: (1) Dapat 
berempati tehadap orang lain, tidak mementingkan diri sendiri, peka terhadap perasaan sesamanya, bersikap dewasa dan bersahabat; (2) Dapat menyesuaian diri dengan situasi yang baru sehingga mekanisme pertahanan dirinya baik; (3) Sikap hidup yang optimis, merasa berguna, memiliki keinginan yang kuat dalam menyelesaikan segala masalah.

Pada masa remaja, salah satu tugas masa perkembangannya adalah mengembangkan ketrampilan konsep intelektual yang penting untuk kompetensi dalam diri individu. Kontrol diri sangat berperan dalam kecenderungan perilaku delikuen pada remaja, karena merupakan salah satu aspek yang harus dimiliki. Havigurst menyatakan bahwa salah satu tugas perkembangan remaja ialah bertanggung jawab sebagai warga negara, mencapai tingkah laku yang bertanggung jawab sosial, serta berkembang dalam pemaknaan nilai-nilai yang ada di masyarakat (Monks, 1999).

Tugas masa perkembangan remaja adalah mencapai kemampuan sosial (social skill) dengan melakukan penyesuaian diri dalam kehidupan sehariharinya. Dalam hal ini, penyesuaian diri merupakan suatu usaha untuk mempertemukan antara tuntutan diri sendiri dengan lingkungannya. Oleh karena itu, timbulnya perilaku-perilaku yang menjurus pada kecenderungan perilaku yang tidak sesuai dengan aturan dan norma-norma yang berlaku dalam masyarakat (delikuen) pada remaja merupakan salah satu bentuk dari maladjustment. Banyak sekali kendalanya, terutama kendala yang bersumber pada karakteristik kepribadian remaja yang merupakan peserta didik, sehingga tidak dapat diarahkan secara bijaksana, maka remaja sebagai peserta didik pada lingkungan pendidikan, akan terjerumus kedalam berbagai perilaku yang salah serta melanggar aturan yang berlaku dan tidak sesuai dengan harapan, seperti yang tampak dalam berbagai kenakalan (perilaku delikuen) pada remaja (Wardani, dkk.,1994).

Setelah mengkaji teori-teori tentang Kontrol Diri, Penyesuaian Diri, dan Perilaku Delikuen, maka hipotesa dalam penelitian ini adalah adanya hubungan antara Kontrol Diri dan Penyesuaian Diri dengan Perilaku Delikuen pada remaja. Semakin tinggi Kontrol diri dan Penyesuaian diri, maka semakin rendah kecenderungan perilaku delikuen pada remaja.

\section{METODE}

Jenis penelitian yang digunakan dalam penelitian ini adalah penelitian korelasional, yaitu suatu jenis penelitian untuk menjelaskan hubungan antar 2 variabel dan meneliti hubungan antara variabel-variabelnya. Setiap penelitian yang ilmiah selalu berhadapan langsung dengan masalah sumber data dan salah satunya adalah populasi. Pada penelitian ini, populasi yang digunakan adalah siswa S. M. A Muhammadiyah Jombang yang berjumlah 113 siswa dengan menggunakan tehnik sampling jenuh yang merupakan pengambilan sampel yang digunakan pada populasi yang semua anggotanya digunakan sebagai sampel.

Tabel 1. Sebaran jumlah Subyek Penelitian

\begin{tabular}{lcc}
\hline Kelas & $\begin{array}{c}\text { Jumlah } \\
\text { Siswa }\end{array}$ & $\begin{array}{c}\text { Jumlah } \\
\text { kehadiran }\end{array}$ \\
\hline X MIA MC 1 & 30 & 28 \\
X MIA MC 2 & 28 & 22 \\
X IIS REG & 29 & 25 \\
X IIS & 26 & 23 \\
\hline Jumlah & 113 & 98 \\
\hline
\end{tabular}

Tehnik pengumpulan data pada penelitian ini menggunakan angket yang disusun berdasarkan Modifikasi Skala Likert (Method of Summated Rating) yang berupa pernyataan tertutup dimana subjek diminta untuk memilih 4 alternatif pilihan jawaban yaitu Sangat Setuju, Setuju, Tidak Setuju, Sangat Tidak Setuju dengan pemberian skor sebagai berikut: (1) Pernyataan yang mendukung 
penelitian (Favourable): Sangat Setuju (nilai 4), Setuju (nilai 3), Tidak Setuju (nilai 2), Sangat Tidak Setuju (nilai 1); (2) Pernyataan yang tidak mendukung penelitian (Unfovoura-ble): Sangat Setuju (nilai 1), Setuju (nilai 2), Tidak Setuju (Nilai 3), Sangat Tidak Setuju (Nilai 4)

Penyusunan angket pada variabel X1 (Kontrol diri) berdasarkan teori dari Logue dan Forzano (1995), karakteristik atau ciri remaja yang mampu memiliki kontrol diri yang tinggi, yang akan dijadikan sebagai indikator tingkah laku dalam penelitian adalah sebagai berikut:

(1) Tekun dan tetap bertahan dengan tugas yang harus dikerjakan, walaupun menghadapi banyak hambatan; (2) Dapat mengubah perilaku menyesuaikan dengan aturan dan norma yang berlaku dimana ia berada; (3) Tidak menunjukkan perilaku yang emosional atau meledak-ledak; (4) Bersifat toleran atau dapat menyesuaikan diri terhadap situasi yang tidak dikehendaki.

Penyusunan angket pada variabel X2 (Penyesuaian diri) berdasarkan teori dari Subsada (dalam Sarwono, 1995), karena teori tersebut cukup komprehensif dan relevan sebagai indikator tingkah laku, yaitu: (1) Dapat berempati terhadap orang lain, seperti tidak mementingkan diri sendiri, peka terhadap perasaan sesama, dan mampu menjalin hubungan dengan orang lain; (2) Dapat beradaptasi di lingkungan yang baru, seperti teman, situasi, dan tempat baru; (3) Memiliki sikap hidup yang optimis, seperti merasa berguna dan memiliki keinginan kuat dalam menyelesaikan masalah

Penyusunan angket pada variabel Y (Perilaku delinkueni) berdasarkan penelitian dari Aroma, I. S., \& Suminar, D. R. (2012), karakteristik atau ciri remaja yang memiliki kecenderungan berperilaku delinkuen yang akan dijadikan sebagai indikator tingkah laku yaitu antara lain: (1)
Kenakalan yang melawan status (mengingkari status anak sebagai pelajar dengan cara membolos, minggat dari rumah, membantah perintah); (2) Kenakalan yang menimbulkan korban fisik (tawuran antar sekolah, berkelahi dengan teman satu sekolah, pemerkosaan, pembunuhan dan lain sebagainya); (3) Kenakalan yang menimbulkan korban materi (memalak, merusak fasilitas sekolah maupun fasilitas umum lainnya dan lain-lain); (4) Kenakalan yang membahayakan orang lain dan diri sendiri (pelacuran, hubungan seks bebas, narkoba dan lain sebagainya.

Azwar S. (1999) berpendapat bahwa analisis validitas dilakukan dengan menghitung koefisien korelasi antara distribusi skor item dan distribusi skor test atau total. Cronbach (Azwar S., 1999) menyatakan bahwa dalam proses validitas tes, sebetulnya tidak bertujuan untuk melakukan validitas tes, tetapi interpretasi dari yang diperoleh dengan prosedur tertentu. Uji validitas dilakukan dengan mengkorelasikan nilai setiap item dengan skor total dan menggunakan tehnik analisa Product Moment, dan dalam perhitungan validitasnya, peneliti menggunakan program SPSS seri 22 for IBM.

Reliabilitas adalah indeks yang menunjukkan kemampuan alat ukur yang dapat dipercaya atau dapat diandalkan. Azwar S. (1999) menyatakan bahwa reliabilitas adalah sejauhmana hasil pengukuran dapat dipercaya. Angket variabel Kontrol diri terdiri dari 10 aitem dan 18 aitem yang gugur dengan nilai Croanbach alpha $(\alpha)$ 0,724. Variabel Penyesuaian diri yang terdiri 20 aitem dan 12 aitem yang gugur dengan nilai Croanbach alpha $(\alpha) 0,815$, sedangkan variabel delinkuen terdiri dari 20 aitem dengan nilai alpha $(\alpha)$ 0,905 dari Croanbach.

Penelitian ini menggunakan analisis korelasi, yaitu analisis yang digunakan untuk melihat atau menyelidiki hubungan antara dua 
variabel. Analisa data yang digunakan adalah statistik dengan tehnik korelasi dan diolah menggunakan komputer program SPSS seri 22 for IBM Windows dengan berdasar pada tujuan penelitian yaitu untuk membuktikan ada hubungan yang positif antara kontrol diri dan penyesuaian diri dengan perilaku delinkuen pada remaja.

\section{HASIL}

Penelitian ini menggunakan kuisioner sebagai alat ukur yang disebar kepada seluruh siswa kelas $\mathrm{X}$ yang berjumlah 113, namun ada beberapa siswa yang tidak hadir karena harus mewakili sekolah dalam lomba Palang Merah Remaja dan karena alasan kesehatan sehingga tersisa 98 siswa yang mengisi kuisioner. Data dari 98 kuisioner yang dikembalikan,tidak memiliki karakteristik tertentu karna selain mengisi pernyataan dalam kuisioner, subjek hanya memberikan inisial nama. Hasilnya kemudian dianalisis. Pada uji validitas mengguanakan nilai minimal 0,250 sehingga bisa dikatakan valid $(\mathrm{p}=0,000)$ karena $\mathrm{r}$ hitung $>\mathrm{r}$ tabel. Berdasarkan hasil analisis tersebut, pada angket Kontrol diri didapat 15 aitem yang valid dan 13 aitem yang gugur. Selain itu pada angket Penyesuaian diri dihasilkan 26 aitem yang dinyatakan valid dan 6 aitem yang gugur. Pada uji normalitas memiliki nilai absolute $(\mathrm{p}=-0,037)$ untuk variabel Kontrol diri dan $(\mathrm{p}=-0,096)$ pada variabel Penyesuaian diri. Dengan demikian kedua variabel tersebut tidak normal karena nilai $\mathrm{p}<0,05$. Sedangkan pada penelitian ini menghasilkan linearity dengan nilai $\mathrm{p}=0,174$ (Kontrol diri) dan $\mathrm{p}=0,072$ (Penyesuaian diri) sehingga hubungan variabel dalam penelitian tersebut dikatan tidak linear karena $p>0,05$.

Peneliti kemudian menggunakan uji statistik non parametric yaitu korelasi Spearman, karena data dari penelitian yang tidak normal dan tidak memiliki hubungan yang linear antara Kontrol diri dan Penyesuaian diri dengan perilaku Delinkuen. Setelah dilakukan uji asumsi, maka dilanjutkan dengan melakukan uji hipotesis. Berdasarkan hasil penelitian yang menunjukkan nilai signifikansi 0,721 dan korelasi koefisien -0,037 pada Kontrol diri dengan delinkuen, dan nilai signifikansi 0,345 dengan korelasi koefisien -0,096 pada Penyesuaian diri dengan delinkuen $(p>0,05)$ berada pada taraf tidak signifikan. Hal ini berarti bahwa tidak ada hubungan yang signifikan antara Kontrol diri dan Penyesuaian diri dengan perilaku Delinkuen. Dengan demikian hipotesis awal ditolak.

Dari hasil hasil analisis deskriptif, peneliti mencoba untuk menjabarkan pengelompokan data dari kategori frekuensi rendah, sedang, dan tinggi. Pada variabel kontrol diri kategori Rendah (11-15) berjumlah 14 siswa, Sedang (16-25) berjumlah 71 siswa, dan kategori Tinggi (26-32) sebanyak 13 siswa. Variabel Penyesuaian diri dengan kategori Rendah (44-55) sebanyak 12 siswa, Sedang (56-71) sebanyak 67 siswa, dan Tinggi (72-80) sebesar 19 siswa. Sedangkan pada perilaku Delinkuen hanya terdapat rentang Sedang (20-33) sebanyak 84 siswa dan kategori Tinggi (34-56) sebanyak 14 siswa.

\section{DISKUSI}

Setelah melakukan pengolahan data, hasil penelitian menunjukkan bahwa tidak ada hubungan yang signifikan antara kontrol diri dan penyesuaian diri dengan perilaku delinkuen. Hal ini bisa dipengaruhi oleh beberapa aspek, yaitu cara pengisian reponden yang asal-asalan atau perilaku Delinkuen pada subjek yang dipengaruhi oleh faktor lain, misalnya hubungan kedekatan dengan keluarga, hubungan kedekatan dengan teman sebaya, dukungan lingkungan sosial sekitarnya, atau faktor-faktor yang lain. Siegel \& Wesh (2011) menyatakan bahwa bahwa 
keluarga, sekolah, dan teman sepermainan merupakan faktor penyebab dari perilaku kenakalan pada remaja. Banyak ahli yang percaya bahwa keluarga yang bermasalah merupakan penyebab utama dalam pembentukan masalah emosional pada anak yang dapat mengarah pada masalah sosial dalam jangka panjang. Orang tua yang mengacuhkan atau tidak memenuhi kebutuhan anak dengan baik akan meningkatkan resiko keterlibatan anak dalam perilaku sosial yang tidak dapat diterima, seperti agresi dan masalah perilaku ekternal lainnya (Veerlan \& Schwartzman, 2002). Pernyataan tersebut didukung oleh penelitian yang menyebutkan sebuah meta analisis yang dilakukan oleh Hoeve, Dubas, Eichelsheim, van der Laan, Smeenk dan Gerris (2009) yang menemukan bahwa pengawasan orangtua, baik pengawasan aktif oleh orangtua, pengetahuan orangtua tentang anaknya dan keterbukaan anak memiliki hubungan yang kuat dengan perilaku delinkuensi remaja, utamanya perilaku delinkuensi remaja yang tampak (overt delinquency).

\section{SIMPULAN}

Berdasarkan hasil pengolahan data pada penelitian ini yang diperoleh dengan menggunakan tehnik sampling jenuh, maka dapat disimpulkan bahwa tidak ada hubungan yang signifikan antara Kontrol diri dan Penyesuaian diri dengan perilaku Delinkuen pada pelajar kelas X Sekolah Menengah Atas Muhammadiyah 1 Jombang. Meskipun demikian, peneliti berharap ada penelitian-penelitian berikutnya yang meneliti dan membahas variabel-variabel yang lain yang lebih berpengaruh pada perilaku delinkuen, karena banyak faktor yang mengindikasikan memiliki pengaruh pada kecenderungan individu dalam berperilaku delinkuen baik itu faktor dari dalam maupun faktor luar seperti pengaruh lingkungan sekitar, dalam hal ini lingkungan keluarga, sekolah dan terutama hubungan dengan teman sepermainan.

\section{DAFTAR PUSTAKA}

Azwar, Saifuddin. (1999). Reliabilitas dan Validitas Cetakan Ketiga. Yogyakarta: Pustaka Belajar.

Azwar, Saifuddin. (1999). Penyusunan Skala Psikologi Cetakan Ketiga. Yogyakarta: Pustaka Belajar.

Azwar, Saifuddin. (1999). Dasar-dasar Psikometri. Yogyakarta: Pustaka Belajar.

Chaplin, J. P. (2006). Kamus Lengkap Psikologi. Jakarta: Rajawali Perss.

Chapple, L. C. (1996). Self-Control, Peer Relations, and Deliquency. Justice Quartelly. 22 (1), 89-96.

Gottfredson, M. R. \& Hirschi, T. (1990). A General Theory of A Crime. Stanford: Stanford University Press.

Gunarsa, S. D. (2004). Dari Anak sampai Usia Lanjut: Bunga Rampai Psikologi Perkembangan. Jakarta: PT BPK Gunung Mulia.

Gunarsa, S. D. (2010). Psikologi Perkembangan Anak dan Remaja. Jakarta: PT Gunung Mulia.

Hoeve, M., Dubas, J.S., Eichelsheim, V. I., van der laan, P.H., Smeenk, W., \& Gerris, J. R. M. (2009). The relationship between parenting and delinquency: a meta analysis. Journal of Abnormal Child Psychology 37: 749-775

Hurlock, E. B. (1973). Adolescent Development (4th ed). Tokyo: Mc Graw-Hill Kogakusha Ltd. 
Iga, S. A. dan Dwi, R. S. (2012). Hubungan antara Tingkat Kontrol Diri dengan Kecenderungan Perilaku Kenakalan Remaja. Jurnal Psikologi Pendidikan dan Perkembangan. Vol. 01 No. 02, Juni 2012, hal 3-4.

John H. Boman IV, Marvin D. Krohn, Chris L. Gibson, \& John M. Stogner (2012). Investigating Friendship Quality: An Exploration of Self-Control and Social Control Theories' Friendship Hypotheses. Journal of Educational Psychology, 2012.

Kartono, K. (1995). Psikologi Anak. Bandung: Alumni.

Kartono, K. (1992). Patologi Sosial 2: Kenakalan Remaja. Jakarta: Rajawali Press, hlm 65.

Logue, A.W., \& Forzano, L.B. (1995). Self Control and Impulsiveness in Children and Adults of Food Preferences. Journal of The experimental Analysis of Behavior, 64 (1), 33-46

Monks, F., Knoers, A., \& Hadito, S. R. (1999). Psikologi Perkembangan: Pengantar dalam berbagai bagiannya. Yogyakarta: Gadjah Mada University Press.

Muhid, A. (2009). Hubungan Antara Self - Control dan Self - Efficacy Dengan Kecenderungan Perilaku Prokrastinasi Akademik Mahasiswa Fakultas Dakwah IAIN Sunan Ampel Surabaya. Jurnal Ilmu Dakwah. Vol,18.

Nindya P.N, Margaretha R. (2012). Jurnal Psikologi Klinis dan Kesehatan Mental Vol.1.No.02.,Juni 2012.
Sarwono, S. (1995). Sosiologi Kesehatan Beberapa Konsep beserta Aplikasinya. Yogyakarta: Gadjah Mada Press.

Siegel, J. \& Welsh, B. (2011). Juvenile Delinquency The Core. California: Wadsworth.

Tri D. T, Haryanti (2006). Hubungan antara Penyesuaian diri dengan Motivasi Belajar pada Siswa, Skripsi (tidak diterbitkan)

Verlaan, P., \& Schwartzman, A. E. (2002). Mother's and Father's Parental Adjustment: Links To Eksternalising Behavior Problem in Sons and Daughters. The International Journal of Behavioral Development, 26, 214224.

Wahida, S. (2011). Pengaruh Dukungan Orang Tua dan Self-Control Terhadap Kecenderungan Kenakalan Remaja, Skripsi (tidak diterbitkan).

Wardani, I. G. A. K, Heru M., dan Sugeng H. (1994). Perkembangan Peserta Didik. Jakarta: Universitas Terbuka.

4 Juta Pengguna Narkoba Terbesar Pelajar dan Mahasiswa (2016, 28 February). Diakses pada tanggal 14 Oktober 2016 dari http://www.surabayanews.com/20 16/02/4-juta-penggunaterbesar.html 